\title{
Analisis Pajak Penghasilan atas Transaksi E-Commerce di Kabupaten Gresik
}

\author{
Emma Rosalinawati ${ }^{1}$, Syaiful $^{2 *}$ \\ ${ }^{1,2}$ Universitas Muhammadiyah Gresik
}

\begin{abstract}
Taxes on online transactions become one of the expansion of tax revenues which presents a challenge for the taxation system in Indonesia. Basically the obligation of taxpayers of conventional businesses and online businesses (e-commerce) is no different. Gresik is one of the regencies in the East Java region where people like to make buying and selling transactions online. The study uses a normative and empirical approach in Gresik Regency which is applied by conducting library studies and field studies through data collection from the results of interviews that will be conducted to; e-commerce players from Gresik Regency, Tax Practitioners Tax Service Office (KPP) North Gresik and academics who master taxation. The results of interviews with e-commerce actors obtained information that most e-commerce actors did not agree with the imposition of tax collection on transactions on e-commerce transactions. The head of the extensification and extension section at the Gresik North Tax Service Office revealed that the potential of online business transactions in Gresik is growing very rapidly but the limited data available so far the North Gresik Tax Office has not been able to distinguish the payment of taxes on e-transactions commerce and conventional.
\end{abstract}

Keywords: Taxpayers, Income Tax, E-Commerce, Online Transactions

Tipe artikel: Empiris

\section{Pendahuluan}

\subsection{Latar Belakang Masalah}

Menurut Wibawa (2010), fenomena e-commerce di Indonesia sudah dikenal sejak tahun 1996 dengan munculnya situs http://www.sanur.com/ sebagai toko buku online pertama. Fenomena jual beli $e$ commerce telah mengubah proses bisnis tradisional menjadi bisnis berbasis digital dengan menghilangkan inefisiensi pasar sehingga terbentuk suatu bisnis dengan dimensi baru. E-commerce merubah proses pemasaran yang sebelumnya dilakukan secara konvensional beralih ke model pemasaran melalui sitem digital. Pemerintah telah mengatur aturan terkait $e$-commerce dalam beberapa kajian hukum. Diantaranya tercantum pada Undang-undang (UU) No. 7 tahun 2014 tentang perdagangan yang menjelaskan kepastian hukum serta kesepahaman mengenai Perdagangan Melalui Sistem Elektronik (PMSE) dan konsumen dalam melakukan kegiatan perdagangan melalui sistem elektronik.

\footnotetext{
${ }^{*}$ Penulis yang sesuai:

E-mail: syaiful@umg.ac.id

Afiliasi: Universitas Muhammadiyah Gresik
} 
Demikian juga Peraturan mengenai perpajakan e-commerce juga telah dijelaskan oleh pemerintah melalui Surat Edaran Direktorat Jenderal Pajak Nomor SE/62/PJ/2013 tentang Penegasan Ketentuan Perpajakan Atas Transaksi e-commerce dan Surat Edaran SE-06/PJ/2015 tentang Pemotongan dan atau Pemungutan Pajak Penghasilan atas Transaksi e-commerce. Peraturan tersebut terdiri dari Pajak Penghasilan (PPh) dan Pajak Pertambahan Nilai (PPN) atas transaksi e-commerce yang meliputi Pajak atas proses bisnis jasa penyediaan tempat dan/atau waktu (online market place), pajak atas proses bisnis penjualan barang dan/atau jasa (classified ads), pajak atas proses bisnis penyetoran hasil penjualan kepada online market place merchant oleh penyelenggara online market place (daily deals) dan pajak atas online retail.

Surat Edaran Direktur Jenderal Pajak Nomor SE/62/PJ/2013 tentang Penegasan Ketentuan Perpajakan Atas Transaksi e-commerce dan Surat Edaran SE-06/PJ/2015 tentang Pemotongan dan atau Pemungutan Pajak Penghasilan atas transaksi e-commerce merupakan bentuk penegasan hukum atas pengenaan pajak transaksi e-commerce yang mengisyaratkan bahwa ketentuan perpajakan terkait dengan transaksi atas $e$-commerce sama ketentuannya dengan perpajakan konvensional yang terdiri dari mendaftar, menghitung, membayar dan melapor bagi setiap pelaku usaha yang melakukan kegiatan $e$ commerce.

Menurut Nufransa yang menjabat sebagai Kepala Subdit Manajemen Transformasi dalam Seminar Perpajakan (2014) mengungkapkan bahwa meski pasar E-Commerce berkembang pesat di Indonesia namun baru segelintir pelaku E-Commerce yang sudah memiliki Nomor Pokok Wajib Pajak (NPWP). Ada 1.600 (seribu enam ratus) sampling (pelaku E-Commerce) yang dicoba, dari jumlah itu ada 600 (enam ratus) yang belum teridentifikasikan dan 1.000 (seribu) sudah teridentifikasikan. Dari 1.000 (seribu) pelaku usaha baru 620 (enam ratus dua puluh) yang sudah memiliki Nomor Pokok Wajib Pajak (NPWP) dan sebagian besar sudah melapor namun tidak diketahui pasti pelaporan tersebut sesuai dengan fakta pada saat bertransaksi.

Pada penelitian ini, Kabupaten Gresik merupakan lokasi penelitian, dan Gresik merupakan salah satu kabupaten di wilayah Jawa Timur yang masyarakatnya gemar melakukan transaksi jual beli secara online. Disisi lain, potensi bisnis online di area Gresik mayoritas adalah UMKM namun belum tergarap dengan baik dan harus digali secara optimal. Hingga saat ini Pemerintah berupaya mendorong perkembangan Badan Usaha Milik Desa (BUMDes) secara online melalui gerakan pelatihan untuk peningkatan kapasitas usaha pelaku BUMDes dengan cara memberikan pelatihan packaging (pengemasan) melalui media online serta melakukan sosialisasi pengenaan pajak atas transaksi $e$ commerce di Kabupaten Gresik. Harapan pemerintah dengan adanya penyuluhan tersebut dapat mengembangkan pangsa pasar UMKM melalui sistem digital serta menjadikan para pelaku usaha secara online paham tentang pajak atas transaksi e-commerce sehingga dapat memberikan kontribusi pemasukkan pajak.

\subsection{Rumusan Masalah}

Berdasarkan latar belakang yang sudah dijelaskan sebelumnya, maka rumusan masalah yang akan diteliti diuraikan sebagai berikut : bagaimana penerapan peraturan pemungutan $\mathrm{PPh}$ atas transaksi $e$ commerce di Kabupaten Gresik?

\subsection{Tujuan Penelitian}

Berdasarkan permasalahan yang telah disebutkan sebelumnya maka tujuan penelitian adalah menganalisa pelaksanaan peraturan pemungutan Pajak Penghasilan (PPh) atas transaksi e-commerce yang ada di Kabupaten Gresik.

\section{Tinjauan Pustaka}

\subsection{Penelitian Sebelumnya}

Eviera (2013) meneliti transaksi e-commerce sebagai potensi penerimaan pajak di Indonesia. Hasil penelitian ini mengungkapkan bahwa Subjek Pajak akan dikenakan pajak apabila menerima atau memperoleh penghasilan. Dasar hukum Pajak Penghasilan adalah Undang-Undang No. 7 tahun 1984 tentang Pajak Penghasilan (PPh) sebagaimana telah dirubah dengan Undang-undang Nomor 36 Tahun 
2008. Penelitian ini mengemukakan beberapa saran yang dapat dilakukan oleh Direktorat Jenderal Pajak untuk mempertimbangkan regulasi perpajakan atas transaksi $e$-commerce, yaitu (1) bekerja sama dengan pihak-pihak terkait, seperti APJII dan Departemen Komunikasi dan Informasi; (2) memperhatikan sistem pemungutan pajak yang efektif dan mempertimbangkan modernisasi sistem administrasi perpajakan untuk transaksi e-commerce; (3) melakukan harmonisasi dan konvergensi atas standar Internasional maupun regulasi OECD dan melakukan perjanjian bilateral untuk menghindari pajak berganda.

Penelitian yang dilakukan oleh Resha (2017) menjelaskan bahwa otoritas pendapatan memiliki peran penting dalam mewujudkan potensi penuh e-commerce. Menurut SE-62/PJ/2013 ada empat jenis e-commerce. Di Indonesia dalam ketentuan Undang-Undang Pajak Penghasilan yang berlaku adalah pasal 23/26, asalkan pembayaran tersebut diterima oleh wajib pajak negara yang tidak memiliki P3B dengan Indonesia. Pembentukan badan pengatur diperlukan untuk memantau lalu lintas komunikasi melalui internet untuk mencegah terjadinya kejahatan di dunia maya. Keterbatasan penelitian ini antara lain hanya mengungkap permasalahan pajak e-commerce di Indonesia dimana terjadi peningkatan volume transaksi perdagangan eletronik dengan peraturan yang terbatas pada Surat Edaran Direktorat Jenderal Pajak yaitu SE-62/PJ/2013 tanpa ada peraturan khusus pajak seperti Peraturan Menteri Keuangan. Keterbatasan penelitian hanya mendeskripsikan permasalahan pajak $e$ commerce di Indonesia baik PPh dan PPN. Implikasi penelitian ini adalah bahwa sesuai dengan Surat Edaran Direktorat Jenderal Pajak yaitu SE-62/PJ/2013 dan UU Pajak Penghasilan serta UU Pajak Pertambahan Nilai yang berlaku hingga saat ini, pemerintah dapat membuat kebijakan pembaharuan untuk membendung kejahatan bidang e-commerce dan lebih detail dalam memungut pajak. Hal ini diharapkan agar penerimaan pajak dalam bidang e-commerce meningkat sesuai dengan penetrasi pengguna internet di Indonesia yang terus meningkat setiap tahunnya.

Suriyadi (2015) mengambil penelitian tentang pengaturan perpajakan e-commerce dan penghindaran pajak berganda. Penelitian ini fokus terhadap pemungutan pajak atas transaksi $e$ commerce berdasarkan ketentuan peraturan perundang-undangan perpajakan yang berlaku dikaitkan dengan sengketa hak pemajakan dan berimplikasi terhadap munculnya pajak berganda, sehingga pengenaan sanksi terhadap subjek pajak yang tidak melakukan kewajiban perpajakan tidak dapat diterapkan. Studi ini mengulas pemahaman pemungutan Pajak Penghasilan yang menganut asas sumber dan asas domisili atas subjek pajak luar negeri yang mendapatkan penghasilan dari Indonesia dan melakukan usaha melalui bentuk usaha tetap (BUT). Penelitian ini mengidentifikasi perusahaan $e$ commerce asing yang seharusnya menjadi subjek pajak luar negeri (karena mendapatkan penghasilan dari Indonesia) tidak dapat dipungut PPh begitupun dengan PPN akibat tidak ada peraturan secara spesifikasi mengenai kriteria BUT dalam peraturan perpajakan Indonesia. Apabila dipaksakan secara sepihak untuk pemungutan PPh dan PPN terhadap perusahaan e-commerce asing, maka hal tersebut dapat menimbulkan pajak berganda. Penelitian ini menyimpulkan bahwa pemungutan pajak penghasilan berdasarkan Undang-undang pajak penghasilan yang berlaku di Indonesia mengadopsi asas sumber dan asas domisili dalam pemungutan pajak penghasilan. Pengenaan pajak atas transaksi $e$ commerce yang mencakup lintas Negara maka akan memberatkan pihak yang dikenai pajak, terlebih lagi apabila antara negara kedua belah pihak tidak terdapat perjanjian penghindaran pajak berganda (P3B). Implikasi dari tidak diaturnya mengenai perusahaan e-commerce asing sebagai suatu BUT mengakibatkan perusahaan e-commerce asing yang mendapatkan penghasilan dari Indonesia dan seharusnya dikenakan PPh tidak dapat untuk dikenakan sanksi. Keberlakuan Undang-undang PPh dan undang-undang PPN dikesampingkan apabila terdapat tax treaty antara Indonesia dengan Negara partner. Apabila dipaksakan untuk perusahaan e-commerce asing pada saat ini untuk dikenakan $\mathrm{PPh}$ dan PPN maka dapat menimbulkan pajak berganda bagi perusahaan e-commerce asing.

Cindy dan Yenni (2014) menganalisa perlakuan Pajak Pertambahan Nilai atas transaksi $e$ commerce. Data penelitian diperoleh dari wawancara dengan pihak toko online $\mathrm{X}$. Hasil penelitian ini adalah terdapat kewajiban untuk membayar Pajak Pertambahan Nilai atas transaksi e-commerce, karena pada dasarnya transaksi $e$-commerce tidak ada perbedaan dengan transaksi konvensional hanya yang 
membedakan mekanisme perdagangannya. Sehingga diperlukan adanya penyesuaian kepada beberapa pihak serta kerja sama untuk menerapkan Pajak Pertambahan Nilai. Hasil penelitian ini juga membuktikan bahwa prosedur pengenaan PPN yang dapat diaplikasikan atas transaksi online di Indonesia pada dasarnya sama dengan sistem dan prosedur atas transaksi konvensional. Studi penelitian ini mengemukakan bahwa semua kegiatan serta PPN yang dipungut kepada pembeli dilakukan oleh vendor sedangkan toko online $\mathrm{X}$ hanya membantu untuk memperluas jaringan pemasarannya.

Melissa (2016) melakukan penelitian tentang kebijakan pengaturan Pajak Penghasilan dan Pajak Pertambahan Nilai terhadap transaksi e-commerce yang mengungkapkan bahwa salah satu potensi di bidang perpajakan adalah pajak atas transaksi e-commerce, sehingga Direktorat Jenderal Pajak memberlakukan surat edaran sebagai kebijakan untuk mengoptimalkan penerimaan Negara atas Pajak Penghasilan dan Pajak Pertambahan Nilai terhadap transaksi e-commerce. Pendekatan masalah yang digunakan pada penelitian ini adalah pendekatan hukum normatif dan empiris. Penelitian ini juga menggunakan jenis data yang terdiri dari data sekunder dan data primer yang dikumpulkan dengan wawancara dan dokumentasi analisis data menggunakan analisis kualitatif. Hasil penelitian ini menunjukkan : (1) Pengaturan Pajak Penghasilan dan Pajak Pertambahan Nilai terhadap transaksi $e$ commerce sebagai kebijakan perpajakan diatur dalam Surat Edaran Direktur Jenderal Pajak Nomor SE62/PJ/2013 tentang Penegasan Ketentuan Perpajakan Atas Transaksi E-commerce dan Surat Edaran SE62/PJ/2015 tentang pemotongan dan atau Pemenungutan Pajak Penghasilan atas transaksi e-commerce dengan mengacu kepada Undang-undang Nomor 36 tahun 2008 tentang Pajak Penghasilan dan Peraturan Pemerintah Nomor 1 Tahun 2012 tentang Pajak Pertambahan Nilai Barang dan Jasa serta Pajak Penjualan Atas Barang Mewah yang terdiri dari Pajak Penghasilan dan Pajak Pertambahan Nilai atas transaksi e-commerce, yang meliputi pajak atas proses bisnis jasa penyediaan tempat dan/atau waktu, pajak atas proses bisnis penjualan barang dan/atau jasa, pajak atas proses bisnis penyetoran hasil penjualan kepada online marketplace merchant oleh penyelenggara online marketplace dan pajak atas online retail. (2) Faktor-faktor penghambat pemungutan adalah rendahnya kesadaran pelaku usaha online selaku wajib pajak, belum optimalnya database pelaku usaha online, lemahnya penegakan hukum terhadap wajib pajak serta pelaku usaha online yang belum memiliki NPWP. Saran dalam penelitian ini adalah : (1) Ditjen Pajak perlu meningkatkan sosialisasi kepada pelaku usaha online tentang pentingnya membayar pajak atas transaksi E-Commerce (2) Ditjen Pajak perlu meningkatkan upaya pendataan terhadap pelaku usaha online sehingga potensi pajak penghasilan dan pajak pertambahan nilai dari transaksi E-Commerce akan dapat dioptimalkan.

Aprilia, dkk (2014) melakukan penelitian tentang penanganan dan pengawasan perpajakan dalam rangka intensifikasi di bidang e-commerce (studi Kantor Pelayanan Pajak Pratama Malang Selatan). Penelitian ini bertujuan untuk mendeskripsikan dan menganalisis upaya Kantor Perpajakan di Malang (Kantor Pelayanan Pajak Pratama) dalam menangani dan mengawasi pajak e-commerce. Studi ini menemukan bahwa Direktorat Jenderal Pajak telah mengklasifikasikan beberapa model e-commerce yang membantu petugas mengelola aspek perpajakan. Studi ini juga menemukan beberapa hal tersebut sebagai tingkat kepatuhan yang rendah dari kesulitan wajib pajak untuk melaporkan aktivitas mereka dan kurangnya bantuan perpajakan sistem dan regulasi e-commerce.

\subsection{Landasan Teori}

\subsubsection{Peraturan Perpajakan E-Commerce}

Menurut Pasal 1 angka 1 Undang-undang Nomor 28 Tahun 2007 tentang Ketentuan Umum dan Tata Cara Perpajakan, pengertian pajak adalah kontribusi wajib kepada Negara yang tertuang oleh orang pribadi atau badan yang bersifat memaksa berdasarkan Undang-undang dengan tidak mendapatkan imbalan secara langsung dan digunakan untuk keperluan Negara bagi sebesar-besarnya kemakmuran rakyat.

Sistem pemungutan pajak yang berlaku di Indonesia adalah self assessment system yaitu sistem yang memberikan kepercayaan dan tanggung jawab yang lebih besar untuk menghitung, menyetor dan 
melaporkan sendiri besarnya pajak terutang oleh wajib pajak Pemerintah dalam hal ini aparat perpajakan berkewajiban melaksanakan pembinaan, penelitian dan pengawasan terhadap pelaksanaan pemenuhan kewajiban pajak, salah satunya Pajak Penghasilan.

Aturan terkait e-commerce diatur dalam Undang-undang (UU) No. 7 tahun 2014 tentang perdagangan yang menjelaskan kepastian hukum serta kesepahaman mengenai Perdagangan Melalui Sistem Elektronik (PMSE) dan konsumen dalam melakukan kegiatan perdagangan melalui sistem elektronik. Undang-undang (UU) No. 7 tahun 2014 menyebutkan bahwa setiap pelaku usaha yang memperdagangkan barang dan atau jasa dengan menggunakan sistem elektronik wajib menyediakan data dan atau informasi secara lengkap dan benar. Setiap pelaku usaha dilarang memperdagangkan barang dan atau jasa dengan menggunakan sistem elektronik yang tidak sesuai dengan data dan atau informasi dan penggunaan sistem elektronik tersebut wajib memenuhi ketentuan yang diatur dalam Undang-Undang Informasi dan Transaksi Elektronik. Data dan atau informasi Perdagangan Melalui Sistem Elektronik (PMSE) minimal menyertakan identitas dan legalitas Pelaku Usaha sebagai produsen atau Pelaku Usaha Distribusi, persyaratan teknis barang yang ditawarkan, persyaratan teknis atau kualifikasi Jasa yang ditawarkan, harga dan cara pembayaran barang dan atau jasa serta cara penyerahan barang.

Undang-undang Perdagangan mendefinisikan Perdagangan Melalui Sistem Elektronik (PMSE) sebagai perdagangan yang dilakukan melalui serangkaian perangkat dan prosedur elektronik. Jenis pelaku usaha PMSE meliputi pedagang (merchant) dan Penyelenggara Perdagangan Secara Elektronik (PPSE), terdiri atas Penyelenggara Komunikasi Elektronik, Iklan Elektronik, penawaran elektronik, penyelenggara sistem aplikasi transaksi elektronik, penyelenggara jasa dan sistem aplikasi pembayaran dan penyelenggara jasa serta sistem aplikasi pengiriman barang. Perusahaan PMSE dapat berbentuk orang perseorangan atau badan hukum.

Terkait pengenaan pajak, transaksi perdagangan secara elektronik dikenakan pajak sesuai peraturan perundang-undangan yang berlaku. Pelaku usaha yang menjalankan perdagangan secara elektronik wajib tunduk pada ketentuan perpajakan Indonesia karena dianggap memenuhi kehadiran secara fisik dan melakukan kegiatan usaha tetap di Indonesia. Terkait bea materai, pengenaan bea materai terhadap dokumen bukti transaksi elektronik diberlakukan terhadap bukti transaksi yang dilakukan secara tertulis diatas kertas. Situs yang telah diaudit berhak memperoleh trustmark. Situs yang tidak bertanggung jawab dapat dimasukkan dalam blacklist.

Beberapa kajian Hukum yang akan saling terkait dan/atau saling mempengaruhi dengan adanya transaksi e-commerce diantaranya adalah HAKI (UU Hak Cipta No. 19/2002, Rahasia Dagang No.30/2000, Desain Industri No.31/2000, Desain Tata Letak Sirkuit Terpadu No.32/2000, Paten No.14/2001 dan Merk Np.15/2001, Perlindungan konsumen No.8/1999, Persaingan Usaha yang Sehat No.5/1999, KUH Perdata dan UU Transfer Dana No.3/2011.

\subsubsection{Definisi Pajak Penghasilan}

Pajak Penghasilan diatur dalam Undang-undang Nomor 36 tahun 2008 tentang Pajak Penghasilan adalah pajak yang dipotong atas penghasilan berupa gaji, upah, honorarium, tunjangan dan pembayaran lain dengan nama dan dalam bentuk apapun sehubungan dengan pekerjaan, jasa, atau kegiatan yang dilakukan oleh Wajib Pajak orang pribadi dalam negeri. Pengertian Pajak Penghasilan (PPh) Pasal 21 berdasarkan Peraturan Direktur Jenderal Pajak Nomor PER-32/PJ/2015 adalah pajak atas penghasilan berupa gaji, upah, honorarium, tunjangan dan pembayaran lain dengan nama dan dalam bentuk apa pun sehubungan dengan pekerjaan atau jabatan, jasa, dan kegiatan yang dilakukan oleh orang pribadi subyek pajak dalam negeri.

Subjek pajak penghasilan dikenai pajak apabila menerima atau memperoleh penghasilan. Subjek pajak yang menerima atau memperoleh penghasilan dalam Undang-Undang No. 36 tahun 2008 tentang Pajak Penghasilan ( $\mathrm{PPh}$ ) disebut Wajib Pajak. Wajib Pajak dikenai pajak atas penghasilan yang diterima atau diperolehnya selama satu tahun pajak atau dapat pula dikenai pajak untuk penghasilan 
dalam bagian tahun pajak apabila kewajiban pajak subjektifnya dimulai atau berakhir dalam tahun pajak.

Pajak Penghasilan merupakan jenis pajak subjektif yang kewajiban pajaknya melekat pada Subjek Pajak yang bersangkutan, artinya kewajiban pajak tersebut dimaksudkan untuk tidak dilimpahkan kepada Subjek Pajak lainnya. Oleh karena itu dalam rangka memberikan kepastian hukum, penentuan saat mulai dan berakhirnya kewajiban pajak subjektif menjadi penting.

\subsubsection{Potensi Pajak Penghasilan atas transaksi E-Commerce}

Definisi e-commerce adalah suatu proses membeli dan menjual produk-produk secara elektronik oleh konsumen dan dari perusahaan ke perusahaan dengan komputer sebagai perantara transaksi bisnis (Laudon and Laudon, 1998, dalam Asih, 2011).

Pemerintah melalui Surat Edaran Dirjen Pajak SE nomor 62/PJ/2013 tentang penegasan kembali tentang pengenaan pajak terhadap transaksi e-commerce ditekankan bahwa pengenaan pajak terhadap transaksi $e$-commerce tetap mengacu kepada peraturan perundang-undangan perpajakan yang berlaku seperti Undang-Undang tentang nomor 16 tahun 2009 tentang penetapan peraturan pemerintah pengganti undang-undang nomor 5 tahun 2008 tentang perubahan keempat atas undang-undang nomor 6 tahun 1983 tentang Ketentuan Umum Perpajakan Dan Tata Cara Perpajakan Menjadi Undang-Undang (undang-undang KUP), Undang-undang nomor 36 tahun 2008 tentang pajak penghasilan (undangundang PPh) dan undang-undang nomor 42 tahun 2009 tentang Pajak Pertambahan Nilai dan Barang Mewah (undang-undang PPN) yang terakhir.

Pada Lampiran Surat Edaran nomor 62/PJ/2013 memberikan gambaran tentang proses bisnis, revenue model, dan contoh penerapan ketentuan-ketentuan sebagaimana dimaksud dalam UndangUndang Ketentuan Umum dan Tata Cara Perpajakan, Undang-Undang Pajak Penghasilan, dan Undang-Undang Pajak Pertambahan Nilai terkait dengan 4 (empat) model transaksi e-commerce, yaitu Online Marketplace, Classified Ads, Daily Deals, dan Online Retail.

\subsubsection{Pengaturan Pemungutan Pajak penghasilan Atas Transaksi E-Commerce}

Pengaturan pemungutan pajak penghasilan atas transaksi E-Commerce dalam Surat Edaran Direktur Jenderal Pajak Nomor SE-62/PJ/2013 tentang Penegasan Ketentuan Perpajakan Atas Transaksi ECommerce adalah sebagai berikut:

\subsubsection{Proses Bisnis Jasa Penyediaan Tempat dan/atau Waktu (Online Marketplace)}

Objek pajaknya adalah penghasilan dari jasa penyediaan tempat dan/atau waktu dalam media lain untuk penyampaian informasi merupakan objek Pajak Penghasilan (PPh) yang wajib dilakukan pemotongan PPh Pasal 21, Pasal 23, atau Pasal 26. Termasuk dalam pengertian media lain untuk penyampaian informasi adalah situs internet yang digunakan untuk mengoperasikan toko, memajang content (kalimat, grafik, video penjelasan, informasi dan lain-lain) barang dan/atau jasa, dan/atau melakukan penjualan. Imbalan sehubungan jasa penyediaan tempat dan/atau waktu dalam situs internet untuk penyampaian informasi dalam contoh proses bisnis Online Marketplace ini dapat berupa Monthly Fixed Fee, Rent Fee, Registration Fee, Fixed Fee, atau Subscription Fee.

Subjek pajaknya adalah orang pribadi atau badan yang memperoleh penghasilan dari jasa penyediaan tempat dan/atau waktu dalam media lain untuk penyampaian informasi. Dengan dasar hukum yaitu Pasal 4 ayat (1) dan ayat (2), Pasal 17, Pasal 21, Pasal 23 dan Pasal 26 UndangUndang PPh.

Tarif untuk Penyelenggara Online Marketplace sebagai penyedia jasa yang penghasilannya tidak dikenai pajak yang bersifat final, tarif PPh Pasal 17 diterapkan atas Penghasilan Kena Pajak yang dihitung dari penghasilan bruto dari penjualan yang dikurangi dengan biaya-biaya untuk mendapatkan, menagih, dan memelihara penghasilan serta untuk Wajib Pajak Orang Pribadi dikurangi dengan Penghasilan Tidak Kena Pajak. Pengaturan ini kurang memenuhi prinsip keadilan sebagai salah satu 
prinsip pengenaan pajak, sebab penghasilan bruto tidak menunjukkan keuntungan bersih dari hasil usaha.

Salah satu prinsip pemungutan pajak adalah prinsip keadilan. Seperti halnya produk hukum pajak pun mempunyai tujuan untuk menciptakan keadilan dalam hal pemungutan pajak. Adil dalam perundang-undangan maupun adil dalam pelaksanaannya. Contohnya adalah dengan mengatur hak dan kewajiban para wajib pajak, pajak diberlakukan bagi setiap warga negara yang memenuhi syarat sebagai wajib pajak dan sanksi atas pelanggaran pajak diberlakukan secara umum sesuai dengan berat ringannya pelanggaran.

Ketentuan Pemotongan PPh adalah apabila Online Marketplace Merchant sebagai pengguna jasa adalah Wajib Pajak Orang Pribadi atau Badan yang ditunjuk sebagai pemotong PPh, maka pengguna jasa tersebut wajib melakukan pemotongan PPh Pasal 23, Pasal 21, atau Pasal 26 sesuai dengan ketentuan yang berlaku. Tarif PPh Pasal 23 atas penghasilan dari jasa penyediaan tempat dan/atau waktu dalam media lain untuk penyampaian informasi adalah sebesar $2 \%$ (dua persen) dari jumlah bruto tidak termasuk Pajak Pertambahan Nilai (PPN). Dalam hal penyedia jasa dimaksud tidak memiliki Nomor Pokok Wajib Pajak, besarnya tarif pemotongan adalah lebih tinggi $100 \%$ (seratus persen), yaitu menjadi sebesar 4\% (empat persen) dari jumlah bruto tidak termasuk PPN.

Tarif PPh Pasal 26 atas penghasilan dari jasa penyediaan tempat dan/atau waktu dalam media lain untuk penyampaian informasi adalah sebesar $20 \%$ (dua puluh persen) dari jumlah bruto tidak termasuk PPN, atau berdasarkan Persetujuan Penghindaran Pajak Berganda (P3B) yang berlaku.

\subsubsection{Proses Bisnis Penjualan Barang dan/atau Jasa (Classified Ads)}

Objek pajaknya adalah penghasilan dari penjualan barang dan/atau penyediaan jasa merupakan objek $\mathrm{PPh}$. Apabila penghasilan dari penjualan barang dan/atau penyediaan jasa merupakan objek pemotongan / pemungutan $\mathrm{PPh}$, maka wajib untuk dilakukan pemotongan / pemungutan $\mathrm{PPh}$. Subjek pajaknya adalah orang pribadi atau badan yang memperoleh penghasilan dari penjualan barang dan / atau penyediaan jasa. Penjual barang atau penyedia jasa dalam contoh proses bisnis Online Marketplace ini adalah Online Marketplace Merchant. Dasar hukumnya adalah Pasal 4 ayat (1) dan ayat (2), Pasal 17, Pasal 21 dan Pasal 22.

\subsubsection{Proses Bisnis Penyetoran Hasil Penjualan Kepada Online Marketplace Merchant oleh Penyelenggara Online Marketplace}

Objek pajaknya adalah penghasilan dari jasa perantara pembayaran merupakan objek $\mathrm{PPh}$ yang wajib dilakukan pemotongan PPh Pasal 23, Pasal 21, atau Pasal 26. Imbalan sehubungan jasa perantara pembayaran dalam contoh proses bisnis Online Marketplace ini dapat berupa Per Sale Fee dan/atau tagihan lainnya. Subjek Pajaknya adalah orang pribadi atau badan yang memperoleh penghasilan dari jasa perantara pembayaran. Penyedia jasa perantara pembayaran dalam contoh proses bisnis Online Marketplace ini adalah penyelenggara Online Marketplace. Dasar hukumnya adalah Pasal 4 ayat (1) dan ayat (2), Pasal 17, Pasal 21, Pasal 23, dan Pasal 26 Undang- Undang PPh.

Tarif untuk pihak Penyelenggara Online Marketplace sebagai penyedia jasa yang penghasilannya tidak dikenai pajak yang bersifat final, tarif PPh Pasal 17 diterapkan atas Penghasilan Kena Pajak yang dihitung dari penghasilan bruto dari penjualan yang dikurangi dengan biaya-biaya untuk mendapatkan, menagih, dan memelihara penghasilan serta untuk Wajib Pajak Orang Pribadi dikurangi dengan Penghasilan Tidak Kena Pajak.

Pemotongan PPh dilakukan dengan ketentuan apabila Online Marketplace Merchant sebagai pengguna jasa adalah Wajib Pajak Orang Pribadi atau Badan yang ditunjuk sebagai pemotong PPh, maka pengguna jasa tersebut wajib melakukan pemotongan PPh Pasal 23, Pasal 21, atau Pasal 26 sesuai dengan ketentuan yang berlaku. Tarif PPh Pasal 23 atas penghasilan dari jasa perantara pembayaran adalah sebesar 2\% (dua persen) dari jumlah bruto tidak termasuk PPN. Dalam hal penyedia jasa dimaksud tidak memiliki Nomor Pokok Wajib Pajak, besarnya tarif pemotongan adalah lebih tinggi 
$100 \%$ (seratus persen), yaitu menjadi sebesar 4\% (empat persen) dari jumlah bruto tidak termasuk PPN.

\subsubsection{Online Retail}

Online retail adalah kegiatan menjual barang dan/atau jasa yang dilakukan oleh penyelenggara online retail kepada pembeli di situs online retail. Objek pajaknya adalah penghasilan dari penjualan barang dan/atau penyediaan jasa merupakan objek PPh. Apabila penghasilan dari penjualan barang dan/atau penyediaan jasa merupakan objek pemotongan/pemungutan $\mathrm{PPh}$, maka wajib untuk dilakukan pemotongan/pemungutan $\mathrm{PPh}$. Subjek Pajaknya adalah orang pribadi atau badan yang memperoleh penghasilan dari penjualan barang dan/atau penyediaan jasa. penjual barang atau penyedia jasa dalam contoh proses bisnis Online Retail adalah Penyelenggara Online Retail. Dasar hukumnya adalah sama dengan dasar hukum bisnis penyetoran hasil penjualan kepada online marketplace merchant oleh penyelenggara online marketplace tersebut di atas.

Tarif untuk pihak Penyelenggara Online Retail (sekaligus Merchant) sebagai penjual barang atau penyedia jasa yang penghasilannya tidak dikenai pajak yang bersifat final, tarif PPh Pasal 17 diterapkan atas Penghasilan Kena Pajak yang dihitung dari : (1). Penghasilan bruto dari penjualan yang dikurangi dengan biaya-biaya untuk mendapatkan, menagih, dan memelihara penghasilan serta untuk Wajib Pajak Orang Pribadi dikurangi dengan Penghasilan Tidak Kena Pajak; atau (2) Penghasilan neto dengan menggunakan norma penghitungan sebagaimana dimaksud dalam Pasal 14 Undang-Undang PPh dan untuk Wajib Pajak orang pribadi dikurangi dengan Penghasilan Tidak Kena Pajak.

\subsection{Proposisi dan Rerangka Konsep}

Kerangka pemikiran pada penelitian ini diambil dari teori-teori dan hipotesis yang diambil dari penelitian sebelumnya. Penulisan penelitian ini dilakukan dengan mengumpulkan data-data yang berasal dari penelitian kepustakaan dan merupakan suatu penelitian dengan mempelajari, mengkaji dan menganalisis data sekunder berupa bahan hukum primer, sekunder, dan tersier. Bahan hukum primer sebagai bahan hukum yang diperoleh langsung dari berbagai peraturan perundang-undangan yang terkait dengan perpajakan. Jenis data dalam penelitian ini adalah data kualitatif fenomenologi deskriptif, data penelitian disajikan sesuai dengan fenomena yang ada disekitar ruang lingkup penelitian dan dideskripsikan dalam bentuk kata-kata yang mengandung makna, data-data diolah melalui hasil wawancara dan menjabarkan penjelasan mengenai transaksi jual beli secara online beserta bukti-bukti atas transaksi e-commerce seperti bukti transaksi, faktur penjualan serta bukti pengiriman.

Sumber data yang digunakan dalam penelitian ini berasal dari sumber internal yaitu data-data yang diperoleh dari hasil wawancara langsung dengan pelaku transaksi e-commerce baik pihak penjual maupun pihak pembeli. Selain itu, data-data yang diperoleh merupakan data-data atau bukti-bukti atau laporan yang berasal dari pengguna transaksi jual beli secara online yaitu bukti transaksi seperti faktur penjualan serta slip transfer bank, bukti slip pengiriman melalui jasa pengiriman seperti JNE, TIKI, atau via POS serta bukti nota retur (jika ada barang yang dikembalikan). Unit analisis dalam penelitian ini adalah perhitungan $\mathrm{PPh}$ atas transaksi e-commerce yang sesuaikan berdasarkan UU PPh

Perlakuan pemungutan pajak atas transaksi $e$-commerce adalah sama dengan pemungutan pajak atas transaksi jual beli secara konvensional yakni disesuaikan dengan peraturan perundang-undangan yang berlaku. Hanya saja pemungutan pajak terhadap pelaku bisnis e-commerce membutuhkan proses penangkapan atau penjaringan data yang cukup sulit sehingga mendeteksi transaksi $e$-commerce melalui media internet (dunia maya) menjadi tantangan baru bagi pihak DJP. Berikut adalah kerangka konsep potensi perpajakan E-commerce. 


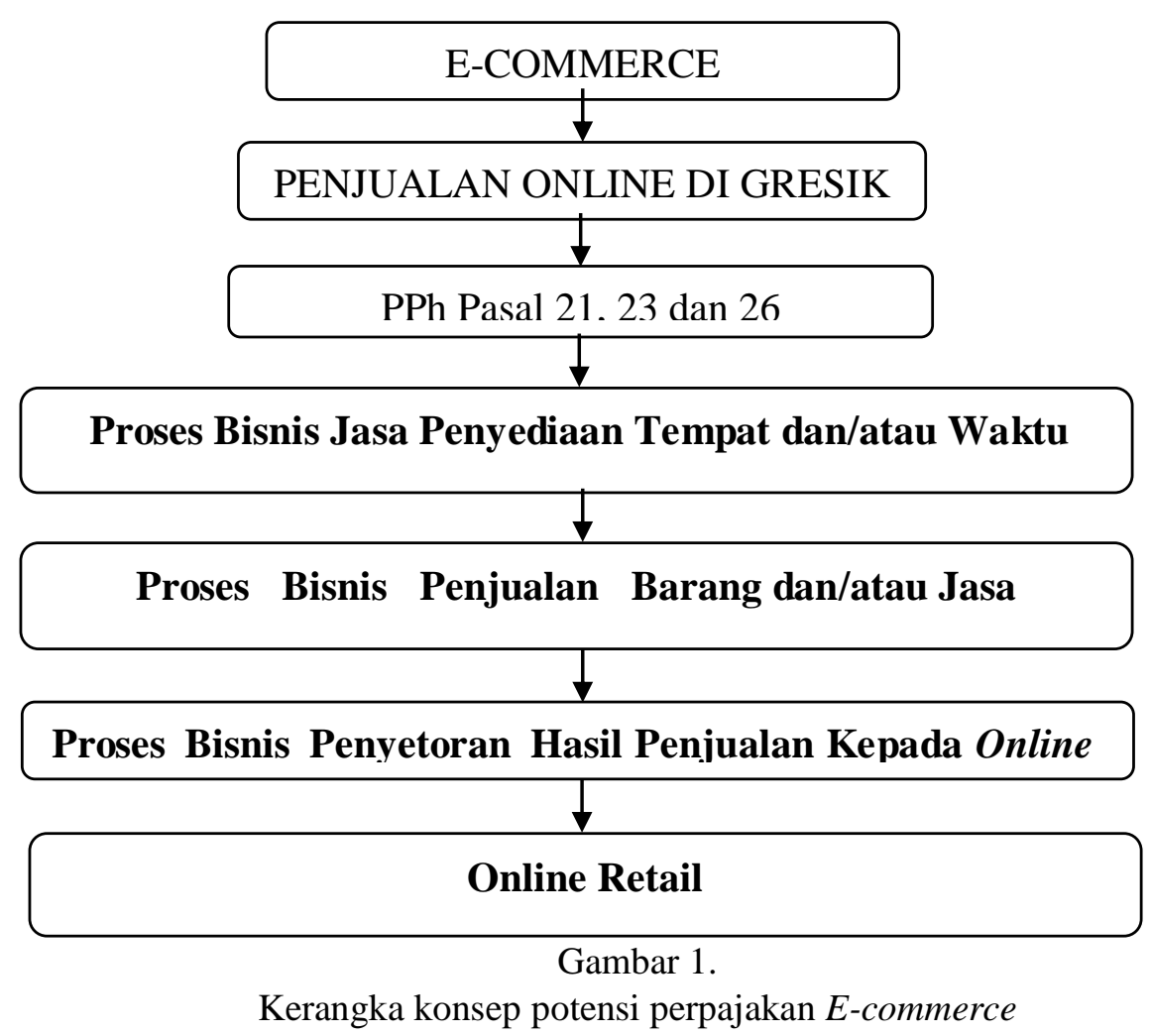

\section{Metode Penelitian}

\subsection{Pendekatan Penelitian}

Pendekatan penelitian ini adalah dengan pendekatan kualitatif yang dilakukan dengan menguraikan data-data yang diperoleh secara deskriptif dengan menggunakan pendekatan penelitian fenomenologi. Menurut Moleong (2005:6) penelitian kualitatif merupakan penelitian yang bermaksud untuk memahami fenomena mengenai hal yang dialami oleh subjek penelitian dengan cara deskripsi dalam bentuk kata-kata dan bahasa, pada suatu konteks khusus yang alamiah dengan memanfaatkan berbagai metode ilmiah. Penelitian ini menggunakan pola non-liner (cyclical) yang memungkinkan peneliti untuk mengulang langkah-langkah penelitian hingga tercapai hasil optimal (logic in practice).

\subsection{Lokasi Penelitian}

Lokasi penelitian merupakan tempat penelitian ini dilakukan. Penelitian ini mengambil lokasi di wilayah Gresik dengan subjek penelitian yaitu para pengusaha online yang berdomisili Gresik dan menggeluti usaha online kurang lebih selama dua tahun lamanya. Informan menjadi komponen penting dalam penelitian kualitatif. Data penelitian diperoleh dari pernyataan dan pendapat seorang informan. Infoman dalam penelitian ini adalah staf Kantor Pelayanan Pajak (KPP) Gresik utara, pelaku online shop yang berasal dari Kabupaten Gresik dan Praktisi atau akademis yang menguasai ilmu perpajakan e-commerce.

Peneliti memilih bapak Suhermadi sebagai informan. Hal ini dikarenakan Suhermadi adalah Kasie (Kepala Seksi) bagian ekstensifikasi dan penyuluhan di Kantor Pelayanan Pajak (KPP) Gresik utara sehingga beliau dapat memberikan informasi akurat tentang peraturan pengenaan pajak atas transaksi e-commerce; Abdullah Mujaddid, S.E.,M.M untuk informan praktisi atau akademis $e$-commerce; bapak Solihin dan ibu Dian Wulandari sebagai pelaku e-commerce sekaligus pemilik toko online yang menjual barang elektronik.

\subsection{Jenis dan Sumber Data}


Jenis dan sumber data untuk penelitian dapat diperoleh dari berbagai macam hal. Berdasarkan cara memperoleh data penelitian, sumber data untuk penelitian berasal dari dua sumber yaitu sumber data primer dan data sekunder. Data primer adalah data yang diperoleh langsung dari sumbernya, contohnya data yang diperoleh dari responden melalui kuesioner, kelompok fokus, panel atau juga data hasil wawancara peneliti dengan narasumber. Sedangkan menurut Sugiono (2012:62), sumber data sekunder adalah sumber data yang tidak langsung memberikan data kepada peneliti atau data yang diperoleh peneliti dari sumber yang sudah ada, misalnya catatan, dokumentasi perusahaan, data yang diperoleh dari majalah dan lain sebagainya. Sumber data dalam penelitian ini diperoleh melalui hasil wawancara peneliti dengan narasumber sedangkan sumber data sekunder diperoleh dari UU PPh e-commerce.

Sedangkan jenis perolehan data pada penelitian ini adalah:

a. Studi Lapangan (Field Research)

Studi Lapangan dilakukan dengan metode Wawancara dengan pihak-pihak yang terkait dengan pembahasan masalah penelitian serta dilakukan mendalam untuk mendapatkan informasi yang diinginkan. Wawancara dilakukan dengan pedoman wawancara yang telah disiapkan peneliti namun tidak menutup kemungkinan peneliti mengajukan pertanyaan diluar pedoman wawancara yang akan berguna dalam menggali lebih rinci perihal pembahasan penelitian. Wawancara penelitian ini dilakukan dengan menggali informasi-informasi yang relevan. Mengadakan tanya jawab atau wawancara untuk memperoleh data secara langsung dengan para pegawai kantor pajak yang berkompeten dalam bidangnya, para professional di bidang hukum pajak dan para ahli di bidang $e$ commerce. Narasumber atau informan yang dihadirkan dalam penelitian ini merupakan informan kunci yang disengaja dipilih oleh peneliti.

b. Studi Virtual, yaitu mengumpulkan data-data serta bahan-bahan yang diperoleh dari situs di internet.

\subsection{Teknik Pengambilan Data}

Teknik pengambilan data adalah teknik atau cara-cara yang digunakan oleh peneliti untuk pengumpulan data. Teknik pengumpulan data merupakan langkah yang paling utama dalam proses penelitian, karena tujuan utama dari penelitian adalah mendapatkan data. Teknik pengumpulan data yang diperlukan adalah teknik pengumpulan data yang paling tepat, sehingga benar-benar didapat data yang valid dan reliable. Dalam penelitian ini, pengambilan data dilakukan dengan wawancara mendalam dengan informan yang telah ditentukan. Penelitian kualitatif ini akan menghasilkan suatu penelitian yang bersifat naturalistic karena penelitiannya dilakukan pada kondisi yang alamiah (natural setting), data yang terkumpul dan analisisnya lebih bersifat kualitatif.

\subsection{Unit Analisis}

Unit analisis merupakan suatu yang berkaitan dengan fokus yang diteliti. Unit analisis merupakan suatu penelitian yang dapat berupa benda, individu, kelompok, wilayah dan waktu tertentu sesuai dengan fokus penelitiannya. Menurut Hamidi (2005: 75-76) menyatakan bahwa unit analisis adalah satuan yang diteliti yang bisa berupa individu, kelompok, benda atau suatu latar peristiwa sosial seperti aktivitas individu atau kelompok sebagai subjek penelitian.

Unit (satuan) analisis data penelitian ini adalah pelaku bisnis e-commerce yang berada di kabupaten Gresik. Peneliti mengumpulkan data-data yang berhubungan dengan bisnis e-commerce yang berada di kabupaten Gresik berdasarkan hasil wawancara, observasi, dan studi literature kemudian dianalisis dengan menghubungkan aturan perpajakan e-commerce hingga di dapatkan suatu kesimpulan fenomena e-commerce di kabupaten Gresik. 


\subsection{Teknik Analisis Data}

Pada penelitian kualitatif pada dasarnya analisis data mempergunakan pemikiran logis, analisis dengan logika, dengan induksi, deduksi, analogi, komparasi dan sejenisnya. Stevict, dkk (2008) mengemukakan pendapat tahapan analisis data fenomenologi sebagai berikut :

a. Menetapkan lingkup fenomena yang akan diteliti : Penelitian dilakukan dengan menetapkan fenomena yang akan dikaji melalui seorang informan dan memahami perspektif filosofis penelitian.

b. Tahap awal setelah menentukan lingkup fenomena adalah mendeskripsikan sepenuhnya fenomena yang dialami subjek. Rekaman dan tulisan hasil wawancara ditranskripsikan ke dalam bahasa tulisan.

c. Tahap Horizonalization : peneliti menginventarisasi pertanyaan-pertanyaan yang relevan dengan topik penelitian. Pada tahap penelitian ini, peneliti harus bersikap obyektif dan merinci point-point pentig sebagai data penelitian.

d. Tahap Cluster of Meaning : Proses pengklasifikasian pertanyaan-pertanyaan yang relevan dengan topik penelitian. Pada tahap ini dilakukan: (a) Textural Desciption (deskripsi tekstural) : peneliti mendeskripsikan apa yang dialami oleh individu; (b) Stuctural Description (deskripsi struktural); Peneliti menuliskan fenomena yang dialami oleh para individu. Peneliti juga mencari berbagai makna berdasarkan refleksi penelitian, berupa opini, penilaian, perasaan, harapan subjek penelitian tentang fenomena yang dialaminya.

3.7 Tahap Deskripsi Esensi : Peneliti mengkonstruksi (membangun) deskripsi menyeluruh mengenai makna dan esensi pengalaman subjek.

e. Pelaporan hasil penelitian : Memberikan pemahaman yang lebih baik kepada pembaca tentang bagaimana seseorang mengalami suatu fenomena.

\subsection{Narasumber}

Menurut Kamus Besar Bahasa Indonesia pengertian narasumber adalah Orang yang mengetahui dan memberikan secara jelas atau menjadi sumber informasi atau informan (orang yang memberikan sebuah informasi). Adapun kriteria nasarumber yang sesuai dengan penelitian ini adalah sebagai berikut :

a. Pelaku E-Commerce :

1. Laki-laki atau perempuan dewasa, sehat jasmani dan rohani dengan batas usia sekurangkurangnya 20 tahun dan maksimal berusia 55 tahun.

2. Mempunyai dan menjalankan usaha online, berdomisili dan Ber-KTP Gresik.

3. Menggeluti usaha onlineshop / e-commerce kurang lebih selama dua tahun lamanya.

4. Memiliki onlineshop dan terdaftar di salah satu situs onlineshop nasional (Lazada, Tokopedia, Shopee, Buka Lapak, JD.ID)

5. Wawancara dilakukan pada untuk sample subjek penelitian.

b. Praktisi Konsultan Kantor Pajak Gresik Utara

1. Laki-laki atau perempuan dewasa, sehat jasmani dan rohani dengan batas usia sekurangkurangnya 20 tahun dan maksimal berusia 55 tahun.

2. Bekerja di kantor pajak Gresik Utara dan memahami alur perpajakan PPh E-Commerce.

c. Akademis Perpajakan E-Commerce

1. Laki-laki atau perempuan dewasa, sehat jasmani dan rohani dengan batas usia sekurangkurangnya 20 tahun dan maksimal berusia 55 tahun.

2. Menempuh pendidikan Ilmu Perpajakan.

3. Memahami perpajakan $\mathrm{PPh}$ atas transaksi e-commerce. 


\section{Hasil Penelitian dan Pembahasan}

\subsection{Gambaran Umum Transaksi E-Commerce di Gresik}

Gresik merupakan salah satu kabupaten di Jawa Timur yang masyarakatnya telah melakukan jual beli secara online. Pelaku bisnis online di Gresik berasal dari berbagai kalangan masyarakat. Umumnya mereka adalah pebisnis muda yang melirik kesempatan bisnis melalui media online. Selain itu perdagangan UMKM di Gresik juga mulai merambah dan mengenalkan usahanya melalui media online, Pemerintah kabupaten Gresik juga gencar mengembangkan produk UMKM (Usaha Mikro, Kecil dan Menengah) melalui media online dengan cara membekali para pelaku usaha kecil di desa yang tergabung dalam Badan Usaha Milik Desa (BUMDes) agar piawai melakukan bisnis e-commerce (penjualan online) dan packaging (pengemasan).

Meskipun pebisnis online di Gresik sudah mulai banyak namun mayoritas pebisnis online tersebut belum mengenal dan belum mengetahui bahwa terdapat kewajiban membayar pajak atas transaksi jual beli online. Selain itu, mayoritas pengusaha bisnis online (e-commerce) belum mendaftarkan usaha mereka secara resmi sehingga mereka tidak memiliki NPWP dan bukti ijin usaha. Padahal, Direktorat Jenderal Pajak telah menegaskan pemungutan pajak atas transaksi e-commerce dengan menerbitkan Surat Edaran yakni SE-62/PJ/2013 dan SE-06/PJ/2015.

\subsection{Pelaksanaan Penelitian}

Penelitian ini dilakukan di daerah Kabupaten Gresik. Informan yang diwawancarai berjumlah 4 (empat) orang yang terdiri dari :

a. Pelaku e-commerce sebanyak 2 orang

b. Praktisi sekaligus Kasie (Kepala Seksi) bagian ekstensifikasi dan penyuluhan di Kantor Pelayanan Pajak Gresik Utara

c. Akademis perpajakan e-commerce

Pada setiap melakukan wawancara memakan waktu kurang lebih satu jam untuk masing-masing informan.

\subsection{Hasil Penelitian}

\subsubsection{Analisa Fenomenologi Efektifitas Pengenaan Pajak Atas Transaksi E-Commerce}

Penelitian ini dilakukan dengan mengerjakan tahapan-tahapan yang telah disebutkan pada bagian sebelumnya. Penelitian menggunakan pendekatan kualitatif fenomenologi yang bertujuan untuk memperoleh pemahaman dan menggambarkan realitas komplek. Fokus penelitian ini adalah analisa penerapan Pajak Penghasilan atas transaksi e-commerce di Kabupaten Gresik. Informan yang dipilih dalam penelitian berjumlah 4 (empat) orang yang terdiri dari ; 2 (dua) orang pelaku e-commerce sekaligus pemilik toko online. 1 (satu) orang praktisi sekaligus bekerja sebagai kasie ekstensifikasi dan penyuluhan di Kantor Pelayanan Pajak (KPP) Gresik utara dan 1 (satu) orang akademis perpajakan $e$ commerce.

Berdasarkan hasil wawancara dengan pelaku e-commerce yang bernama bapak Mohamat Solihin diperoleh informasi bahwa beliau tidak mengetahui adanya peraturan tentang pajak e-comerce, namun sebagai masyarakat yang sadar akan kewajiban pajak, beliau tetap membayarkan Pajak Penghasilan pribadi seperti penyataannya dalam wawancara "Kami tidak mengetahui adanya peraturan tentang pajak e-comerce, namun kami membayar pajak penghasilan atas nama pribadi bukan atas nama toko". Menurut peneliti ketidaktahuan tersebut mungkin disebabkan kurangnya pengetahuan ilmu perpajakan terlebih pendidikan pelaku e-commerce hanya sebatas Sekolah Menengah Atas sehingga wajar jika memiliki keterbatasan pengetahuan tentang perpajakan. Selanjutnya, bapak Mohamat Solihin mengungkapkan bahwa. Tanggapan kami sebaiknya pemerintah lebih sering menyosialisasikan 
peraturan tersebut melalui media online dan komunitas jual beli". Menurut peneliti memang sebaiknya pemerintah lebih gencar dan fleksibel dalam menyosialisasikan pajak atas transaksi e-commerce dan sosailisasi dapat dilakukan pada komunitas jual beli online secara bertahap. Hal ini bertujuan agar para pelaku bisnis online dapat mengetahui kewajiban dan menerapkan pajak atas transaksi $e$-commerce dalam bisnis online yang mereka jalankan. Menurut peneliti bapak Mohamat Solihin setuju dan bersedia mentaati peraturan pemungutan pajak atas transaksi e-commerce asalkan regulasinya jelas dan pemotongan $\mathrm{PPh}$ langsung dari pihak ketiga atau penyedia jasa online shop seperti yang diungkapkannya pada saat wawancara "Saya setuju asalkan regulasinya jelas dan pemotongan PPh langsung dari pihak ketiga atau penyedia jasa online shop selain itu, kami menyikapi dengan terbuka asal tidak memberatkan kami para penjual dan pembeli online."

Informan pelaku e-commerce berikutnya berasal dari pemilik online shop yang melakukan perdagangan online berupa pakaian dan perlengkapan anak. Informan tersebut seorang karyawati sebuah perusahaan namun memiliki usaha sampingan berupa online shop dan informan tersebut bernama Ibu Dian Wulandari. Informan melakukan transaksi jual beli online dengan cara membeli barang dagangannya dari pihak agen besar kemudian dijual secara online dan dikirimkan melalui expedisi jasa pengiriman barang. Dari hasil wawancara diperoleh Informasi bahwa informan tidak mengenal dan sebelumnya belum pernah mendengar adanya pengenaan Pajak Penghasilan $\mathrm{PPh}$ atas transaksi jual beli online (e-commerce) seperti yang diungkapkannya "Tidak tahu dan sebelumnya belum pernah mendengar". Informan tersebut juga mengungkapkan bahwa sangat awam mengenal perpajakan sehingga tidak dapat memberikan tanggapan mengenai perpajakan atas transaksi $e$ commerce. Menurut simpulan hasil penelitian informan tersebut kurang setuju, apabila pengenaan pajak atas transaksi e-commerce dijalankan. Perlu adanya regulasi pembatasan tarif pengenaan pajak atas transaksi e-commerce, misal untuk transaksi diatas jual beli online yang sudah mencapai penjualan diatas 10 Juta seperti yang diungkapkannya "Karena saya sangat awam mengenal perpajakan maka saya secara pribadi tidak dapat memberikan tanggapan mengenai perpajakan e-commerce". Informan juga tidak membayarkan pengenaan Pajak Penghasilan atas transaksi e-commmerce yang selama ini dilakukannya.

Berdasarkan hasil pengamatan dan informasi serta keterangan informan praktisi yang sekaligus bekerja sebagai Kasie ekstensifikasi dan penyuluhan Kantor Pelayanan Pajak Gresik Utara yang bernama Suhermadi diperoleh informasi bahwa potensi transaksi bisnis online di Gresik berkembang sangat pesat seperti yang diungkapkannya pada saat wawancara "Tidak dapat dihindari lagi bahwa tren perdagangan melalui jaringan internet (e-commerce) mengalami kemajuan sangat pesat seiring kemajuan teknologi termasuk di gresik”. Di Gresik sendiri Perpajakan E-Commerce tidak dibedakan dengan perpajakan jual beli secara konvensional hal ini karena pihak Kantor Pelayanan Pajak Gresik Utara belum dapat membedakan dan belum dapat mengidentifikasi antara transaksi konvensional dan transaksi e-commerce bapak Suhermadi mengungkapkan "Karena keterbatasan data yang ada, sampai saat saya belum bisa membedakan pembayaran pajak atas usaha dari Transaksi e-commerce dan konvensional". Menurut hasil Study Literature diperoleh informasi bahwa beberapa instansi pemerintah Gresik pun turut serta melakukan pembinaan dan sosialisi agar usaha UMKM berkembang melalui bisnis online diantaranya : Inisiasi dari PT Bank Negara Indonesia (Persero) Tbk atau Bank BNI Kanwil Surabaya melalui Kantor Cabang Gresik bersama Pemkab Gresik menggelar pelatihan para pelaku usaha kecil di desa yang tergabung dalam BUMDes bertempat di Ruang Mandala Bakti Praja yang diadakan pada Rabu, 27 September 2017 berbagai produk dipamerkan, mulai dari makanan, minuman, bahkan sandang ; "Start Up" Seminar pengembangan UKM yang diadakan oleh KPP Pratama Gresik Utara pada tanggal 12 Desember 2017.

Pengusaha e-commerce dapat dikenakan Pajak Penghasilan sesuai dengan Peraturan Pemerintah (PP) 46 Tahun 2013 yakni Peraturan Pemerintah yang mengatur tentang Pajak Penghasilan atas Penghasilan dari usaha yang diterima atau diperoleh wajib pajak yang memiliki peredaran bruto tertentu (UMKM). Objek pajak yang dikenai Pajak Penghasilan berdasarkan ketentuan PP Nomor 46 Tahun 2013 ini adalah penghasilan dari usaha yang diterima atau diperoleh wajib pajak dengan peredaran bruto (omzet) yang tidak melebihi Rp 4.800.000.000 dalam 1 tahun pajak. Peredaran bruto 
(omzet) merupakan jumlah peredaran bruto semua gerai/counter/outlet atau sejenisnya baik pusat maupun cabangnya. Pajak yang terhutang dan harus dibayar adalah $1 \%$ dari jumlah peredaran bruto (omzet). Wajib Pajak yang dikenai Pajak Penghasilan seusai PP No. 46 adalah : Orang Pribadi dan Badan, tidak termasuk Bentuk Usaha Tetap (BUT) yang menerima penghasilan dari usaha dengan peredaran bruto (omzet) yang tidak melebihi $\mathrm{Rp} 4.800 .000 .000$ dalam 1 tahun pajak. Selain itu pemerintah juga telah memberikan penegasan khusus terkait kewajiban pemotongan dan/atau pemungutan Pajak Penghasilan atas transaksi e-commerce yang ditegaskan dalam Surat Edaran Direktur Jenderal Pajak Nomor SE-62/PJ/2013 tentang Penegasan Ketentuan Perpajakan atas Transaksi E-Commerce dan Surat Edaran SE-06/PJ/2015 tentang Pemotongan dan atau Pemungutan Pajak Penghasilan atas Transaksi e-commerce dengan mengacu kepada Undang-undang Nomor 36 tahun 2008 tentang Pajak Penghasilan. sehingga peneliti dapat menyimpulkan bahwa peraturan pemungutan pajak atas transaksi $e$-commerce di Gresik masih belum berjalan secara optimal namun sebagai instansi Pelayanan Pajak maka Kantor Pelayanan Pajak Gresik Utara telah melakukan sosialisasi terkait hal Pengenaan Pajak Penghasilan atas transaksi e-commerce menurut bapak Suhermadi "Karena Pelaku ecommerce tetap merupakan subyek pajak (WP dan Calon WP) KPP Pratama tetap melakukan sosialisasi karena pada prinsipnya semua penghasilan merupakan objek pajak”. Penelitian ini disimpulkan bahwa faktor ketidak efektifan pemungutan Pajak Penghasilan (PPh) atas transaksi $e$ commerce di Gresik disebabkan karena masyarakat awam tidak mengetahui adanya informasi pengenaan pajak atas transaksi e-commerce sebagaimana yang telah disebutkan oleh narasumber "Karena keterbatasan data yang ada, sampai saat ini saya belum bisa mengetahui efektifitas pembayaran pajak dari pengusaha yang melakukan Transaksi e-commerce dan konvensional" selain itu ketidak efektifan pemungutan Pajak Penghasilan atas transaksi $e$-commerce juga dikarenakan faktor kurangnya pengetahuan masyarakat Gresik terhadap peraturan pajak. Mereka sangat awam dengan dunia perpajakan dan cenderung pasif untuk mematuhi pemungutan pajak. Hasil studi Literatur diperoleh bahwa Kantor Pelayanan Pajak Gresik Utara telah beberapa kali melakukan kegiatan sosialisasi terkait pengenaan pajak atas transaksi e-commerce diantaranya:

a. Sosialisasi pada Forum Bisnis E-Commerce Tax yang di selenggarakan bekerjasama dengan Universitas Internasional Semen Indonesia (UISI) Gresik pada Kamis, 19 November 2017 dalam forum ini disampaikan pentingnya pemahaman bisnis dan pajak terkait e-commerce tax dengan pembicara bapak Irwan Sugianto staf ekstensifikasi dan penyuluhan dari Kantor Pelayanan Pajak Gresik Utara.

b. Seminar yang dilakukan pada Kamis, 30 November 2017 Kantor Pelayanan Pajak Gresik Utara mengadakan "Start Up" Seminar Pengembangan UKM sekaligus melakukan sosialisasi terkait pengenaan pajak atas transaksi jual beli online (e-commerce)" dengan pembicara bapak Irwan Sugianto staf ekstensifikasi dan penyuluhan dari Kantor Pelayanan Pajak Gresik Utara.

Hasil wawancara dengan informan bapak Abdullah Mujaddid, S.E.,M.M selaku akademis ilmu perpajakan, mengungkapkan bahwa "meskipun pemerintah sudah menegaskan pengenaan pemungutan pajak atas transaksi e-commerce yang ditegaskan melalui SE-62/PJ/2013 dan SE-06/PJ/2015, namun pemungutan pajak PPN dan PPh atas transaksi e-commerce tersebut masih sulit diterapkan". Menurut peneliti sulitnya penerapan pemungutan pajak PPN dan PPh dikarenakan subyek dan obyek pajak atas transaksi e-commerce bersifat ambigu dan tidak mudah ditelurusi pergerakan arus transaksinya. Oleh karena itu pemerintah perlu mengkaji ulang dasar pemungutan pajak atas transaksi $e$-commerce sebelum menerapkan pemungutan pajak atas transaksi e-commerce. Bapak Mujadid juga menambahkan bahwa "Penerbitan SE-62/PJ/2013 dan SE-06/PJ/2015 oleh Direktorat Jenderal Pajak hanya merupakan suatu bentuk penegasan yang hakikatnya masih lemah secara hokum karena peraturan tersebut bukanlah sebuah undang-undang. Untuk itu apabila pemungutan pajak atas transaksi e-commerce ini diterapkan maka sudah sewajarnya aturan tersebut diterbitkan melalui Keputusan Menteri Keuangan dalam bentuk perundang-undangan".

\subsubsection{Pembahasan}


Perdagangan online melalui media internet di Gresik sangat marak dan banyak peminatnya. Hal ini dikarenakan model bisnis berbasis online atau e-commerce sangat berbeda dengan bisnis konvensional. Pelaku e-commerce dapat memanfaatkan media online melalui internet untuk menjangkau pasar dan melakukan transaksi jual beli. Proses transaksi jual beli dapat dilakukan secara online, namun penggiriman barang dilakukan secara offline dengan memanfaatkan jasa kurir atau ekspedisi pengiriman.

Pekembangan bisnis online yang sangat pesat menjadikanya sebagai salah satu sektor pemungutan pajak yang dapat menambah pemasukan untuk perpajakan di Indonesia. Direktorat Jenderal Pajak telah menerbitkan SE/62/PJ/2013 tentang Penegasan Ketentuan Perpajakan Atas Transaksi e-commerce dan Surat Edaran SE-06/PJ/2015 tentang Pemotongan dan atau Pemungutan Pajak Penghasilan atas Transaksi e-commerce sebagai bentuk penegasan bahwa transaksi atas $e$ commerce (jual beli online) dikenakan pemunggutan pajak. Penetapan pajak atas transaksi e-commerce ini bertujuan untuk menerapkan keadilan bagi semua wajib pajak baik atas transaksi jual beli konvensional maupun e-commerce (online). Pada dasarnya kewajiban wajib pajak pelaku bisnis konvensional dan bisnis online (e-commerce) tidak berbeda. Pajak atas transaksi e-commerce sesuai dengan SE/62/PJ/2013 dan SE-06/PJ/2015 mempertegas bahwa tidak ada pajak baru dalam transaksi $e$ commerce sehingga penjual dan pembeli atas transaksi jual beli secara konvensional maupun $e$ commerce dikenakan pajak sesuai ketentuan perundang-undangan perpajakan yang berlaku.

Berdasarkan hasil wawancara penelitian yang telah dilakukan diperoleh informasi bahwa sebagian besar pelaku bisnis online yang berdomisili di kabupaten Gresik belum mengetahui adanya pengenaan pajak atas transaksi jual beli onlie (e-commerce). Para pelaku e-commerce di Gresik sangat awam dan tidak mengenal perpajakan. Selain itu sebagian besar pelaku e-commerce tersebut belum mendaftarkan usaha online yang mereka miliki. Para pelaku e-commerce yang berasal dari Gresik mengaku keberatan dan tidak setuju apabila pajak atas transaksi $e$-commerce diterapkan. Terlebih dalam usaha online yang mereka jalankan mereka hanya berperan sebagai dropshiper dan marketing dari supplier atau agen besar. Namun, pelaku e-commerce yang bernama bapak Mohamat Solihin setuju dan menyikapi secara terbuka dengan adanya peraturan pemungutan pajak atas transaksi e-commerce namun peraturan tersebut harus memiliki regulasi dan dasar pemungutan yang jelas serta tidak memberatkan para penjual dan pembeli online. Informan bapak Mohamat Solihin juga berpendapat bahwa sebagai pelaku UKM sering kali bermasalah dengan pembukuan sehingga jika tarif pajak yang akan dikenakan dan dihitung oleh sendiri mungkin akan merepotkan namun jika langsung ditetapkan oleh penyedia layanan online shop maka akan sangat memudahkan dan efektif.

Hasil penelitian menyimpulkan bahwa hingga saat ini pemunggutan dan pengawasan terkait pengenaan pajak atas transaksi e-commerce di Gresik penerapannya masih belum efektif. Ada banyak faktor kendala dalam penerapan pemunggutan pajak atas transaksi e-commerce, diantaranya adalah sulitnya melacak alur pergerakan transaksi yang masih ambigu dan tidak transparan sehingga pemerintah masih kesulitan dalam mengidentifikasi pelaku transaksi e-commerce.

\section{Kesimpulan dan Saran}

\subsection{Kesimpulan}

Berdasarkan hasil wawancara dengan para informan dapat disimpulkan bahwa :

a. Hasil wawancara dengan pelaku e-commerce diperoleh informasi bahwa sebagian besar pelaku $e$ commerce tidak setuju dengan diberlakukannya pemungutan pajak atas transaksi jual beli online $(e-$ commerce). Pelaku jual beli transaksi online berpendapat bahwa pemungutan pajak atas transaksi $e$ commerce hanya akan menambah kesemrawutan transaksi jual beli secara online. Hal ini dikarenakan para penjual dan pembeli di media online harus menghitung, menyetor dan melaporkan setiap transaksi yang mereka lakukan kepada Kantor Pelayanan Pajak setempat. Namun diantara 
pelaku e-commerce tersebut masih ada yang membayarkan e-commerce Pajak Penghasilan sebagai pajak pribadi mereka.

b. Menurut praktisi bapak Suhermadi sekaligus selaku Kasie ekstensifikasi dan penyuluhan di Kantor Pelayanan Pajak (KPP) Gresik utara mengungkapkan bahwa potensi transaksi bisnis online di Gresik berkembang sangat pesat. Selain itu diperoleh informasi bahwa Kantor Pelayanan Pajak (KPP) Gresik utara siap melaksanakan pemungutan pajak atas transksaksi $e$-commerce sesuai isi dari Surat Edaran Direktur Jenderal Pajak Nomor SE-62/PJ/2013 tentang Penegasan Ketentuan Perpajakan atas Transaksi E-Commerce dan Surat Edaran SE-06/PJ/2015 tentang Pemotongan dan atau Pemungutan Pajak Penghasilan atas Transaksi e-commerce.

c. Hasil wawancara dengan akademis perpajakan e-commerce dapat disimpulkan bahwa salah satu alasan sulitnya menerapkan pemungutan pajak atas transaksi e-commerce adalah subyek dan obyek transaksi jual beli online (e-commerce) yang masih ambigu dan tidak transparan sehingga tidak mudah untuk ditelusuri bentuk traksaksinya.

\subsection{Saran}

Berdasarkan penjelasan yang disampaikan oleh Djuaniardi (2016) beberapa solusi yang dapat dilakukan dalam membendung maraknya kegiatan e-commerce adalah memperketat izin perdagangan serta izin pembukaan situs dalam rangka berdagang di Indonesia, memonitor data pengiriman, serta memonitor transaksi dan pengguna kartu kredit, perlunya adanya kewajiban bagi pelaku untuk memastikan data transaksi di situs tetap ada sampai jangka waktu tertentu dan perlu adanya ketentuan yang mengatur kewajiban pembayaran melalui satu payment gateway nasional. Membentuk badan pengawas yang bertugas untuk mengawasi lalu lintas komunikasi melalui internet agar tidak menimbulkan terjadinya kejahatan di dunia maya (cybercrime). Melakukan penerapan cyberlaw meskipun butuh waktu lama, karena dari pihak otoritas setidaknya harus membentuk wadah baru serta melatih orang - orangnya melalui pelatihan sehinnga bentuk promosi apapun yang dilakukan di internet tentunya harus dikenai pajak. Mencari data Wajib Pajak yang melakukan usaha secara e-commerce sebenarnya bisa lebih mudah dan valid jika dibandingkan dengan melakukan sensus pajak yang harus mendatangi ruko atau toko satu per satu. Hal yang dilakukan oleh Direktorat Jenderal Pajak dapat mengecek secara langsung website atau situs e-commerce sehingga dapat mengetahui siapa pelaku $e$ commerce tersebut, ditambah lagi biasanya tercantum nomor rekening pihak penjual yang dapat mempermudah untuk mengetahui siapa yang menerima penghasilan tersebut. Oleh karena itu, dalam sistem self assessment ini keberadaan basis data perpajakan yang lengkap dan akurat sangat penting bagi Direktorat Jenderal Pajak (DJP). Data ini akan digunakan untuk membuktikan bahwa penghitungan, penyetoran dan pelaporan pajak yang dilakukan sendiri oleh Wajib Pajak sudah benar. Apabila diketahui masih salah, maka data tersebut akan digunakan sebagai dasar tindakan koreksi.

\section{Daftar Pustaka}

Almanfaluty, Syuhud. 2017. "BUMDes Gresik Diberi Pelatihan tentang e-Commerce dan Packaging". https://www.bangsaonline.com/berita/37678/bumdes-gresik-diberi-pelatihan-tentangecommerce-dan-packaging, Diakses 30 Agustus 2017.

Aprilia, A. 2014. Penanganan Dan Pengawasan Perpajakan Dalam Rangka Intensifikasi DiBidang ECommerce (Studi Pada Kantor Pelayanan Pajak Pratama Malang Selatan). Jurnal Mahasiswa Perpajakan. Vol. 2. No. 1. Pp.1-10.

Badan Pusat Statistik Gresik. 2016. "Jumlah Penduduk Menurut Kelompok Umur" https://gresikkab.bps.go.id/statictable/2017/07/06/86/jumlah-penduduk-menurut-kelompokumur-dan-kecamatan-2014.html. Diakses pada 1 September 2017. 
Direktorat Jenderal pajak, Undang-undang Nomor 28 Tahun 2007 tentang Perubahan Ketiga atas Undang-undang Nomor 6 tahun 1983 tentang Ketentuan Umum dan tata Cara Perpajakan.

Direktorat Jenderal pajak, Undang-undang Nomor 16 Tahun 2009 tentang Perubahan Ketiga atas Undang-undang Nomor 6 tahun 1983 tentang Ketentuan Umum dan tata Cara Perpajakan.

Direktorat Jenderal Pajak Kementerian Keuangan. 2014. "Masih Sedikit Pelaku E-Commerce Yang Memiliki NPWP”. http://www.pajak.go.id/content/masih-sedkit-pelaku-e-commerce-yangmemiliki-npwp. Diakses pada 2 Juni 2017.

Direktorat Jenderal Pajak Kementrian Keuangan. 2017. "45 Pelaku UKM Gresik Ikuti Start BDS Pajak". http://www.pajak.go.id/news/45-pelaku-ukm-gresik-ikuti-start-bds-pajak. Diakses pada 6 September 2017.

Djuniardi, Iwan. 2015. Aspek Perpajakan Transaksi E-Commerce. Makalah disampaikan pada Paparan Ikatan Akuntan Indonesia, Jakarta.

Kementerian Komunikasi dan Informatika Republik Indonesia. 2015. "Indonesia akan jadi pemain ekonomi digital terbesar di Asia https://www.kominfo.go.id/content/detail/6441/indonesia-akan-jadi-pemain ekonomi-digitalterbesar-di-asia-tenggara/0/berita_satker. Diakses pada 10 Oktober 2017

Kementerian Komunikasi dan Informatika Republik Indonesia. 2017. "Gerakan Nasional Go Online". https://www.kominfo.go.id/content/detail/11346/siaran-pers-no-216hmkominfo112017-

tentang-go-digital-gerakan-nasional-umkm-go-online/0/siaran_pers. Diakses pada 1 September 2017.

Kusbiantora, Mahmud.2013. "Pengertian singkat mengenai PP No. 46". http://berdiskusipajak.blogspot.co.id/2013/09/pengertian-singkat-mengenai-pp-no 46.html. Diakses 30 Agustus 2017.

Lestari, Sri Handi. 2017. "Gandeng Pemkab Gresik, BNI Gelar Pelatihan E-Commerce dan packaging untuk BUMDes". http://surabaya.tribunews.com//2017/09/02/27/ gandeng-pemkab-gresik-bnigelar-pelatihan-ecommerce-dan-packing-untuk-bumdes. Diakses 30 Agustus 2017.

Lomanto, N. C dan Mangoting, Y. 2014. "Perlakuan PPN Atas Transaksi E-Commerce". Jurnal Tax \& Accounting Review Universitas Petra Vol. 1, No. 2, 2014.

Lubis, R.M, dkk. 2016. "Kebijakan Pengaturan Pajak Penghasilan Dan Pajak Pertambahan Nilai Terhadap Transaksi E-Commerce". Jurnal Ilmiah Jurusan Hukum Administrasi Negara Fakultas Hukum.

Moleong, L. Y. 2005. Metodologi Penelitian Kualitatif Edisi revisi. Bandung: PT Penerbit Remaja Rosdakarya.

Muniriyanto, Buyung. 2015. "Menelusur Pajak atas Transaksi E-Commerce". Online. http://www.pajak.go.id/content/article, Diakses pada tanggal 14 Agustus 2017.

Pangesti, D. R. 2017. "Menguak Permasalahan Perpajakan E-Commerce Di Indonesia dan Solusi Pemecahannya". Jurnal Riset Akuntansi dan Bisnis Airlangga. Vol. 2. No. 1.

Puspa, Dian. 2016. "Pajak E-Commerce". https://www.online-pajak.com/id/pajak-e-commerce-onlineretail. Diakses pada 2 September 2017. 
Republik Indonesia. Undang-undang Nomor 7 tahun 2014 tentang perdagangan yang menjelaskan kepastian hukum serta kesepahaman mengenai Perdagangan Melalui Sistem Elektronik (PMSE) dan konsumen dalam melakukan kegiatan perdagangan melalui sistem elektronik.

Republik Indonesia. Surat Edaran Direktur Jenderal Pajak Nomor : SE-62/PJ/2013 Tentang Penegasan Ketentuan Perpajakan Atas Transaksi ecommerce.

Republik Indonesia. Undang-Undang Nomor 36 Tahun 2008 tentang Perubahan Undang-Undang No. 7 tahun 1984 tentang Pajak Penghasilan (PPh).

Republik Indonesia. Undang-Undang No. 42 Tahun 2009 tentang Perubahan Undang-Undang No. 8 Tahun 1983 Tentang Pajak Pertambahan Nilai dan atau Penjualan atas Barang Mewah.

Republik Indonesia. Peraturan Pemerintah Nomor 1 tahun 2012 tentang Pajak Pertambahan Nilai Barang dan Jasa serta Pajak Penjualan Atas Barang Mewah.

Suriyadi. 2015. "Pengaturan Perpajakan E-Commerce Dan Penghindaran Pajak Berganda". Jurnal Tesis Fakultas Hukum Fakultas Hukum Universitas Airlangga. Vol. 1. No. 1.

Syadri, Muhammad. 2017. "Jawa Timur Provinsi Terbesar Ketiga Pasar E-Commerce". https://www.jawapos.com/read/2017/03/04/113799/jawa-timur-provinsi-terbesar-ketigapasar-e-commerce. Diakses pada 6 Oktober 2017.

Thidi, Design. 2017. "Pengertian Pajak E-commerce Juga Jenis dan Manfaatnya Bagi Perekonomian”. https://thidiweb.com/pengertian-pajak-e-commerce/. Diakses pada tanggal 14 Agustus 2017.

Utomo, E. M. 2013. “Transaksi E-Commerce Sebagai Potensi Penerimaan Pajak di Indonesia”. Jurnal Mahasiswa Teknologi Pendidikan. Vol.2. No.1. Pp.152-173.

Wibawa, H. 2010. "Perkembangan, Manfaat, dan Kelemahan E-Commerce". http://mhs.blog.ui.ac.id/hari.wibawa/2010/10/28/perkembangan-manfaat-dan-kelemahan-ecommerce/. Diakses pada 1 Juni 2017.

Wikipedia bahasa Indonesia, “Kabupaten Gresik”. 20 Desember 2017. https://id.wikipedia.org/ wiki/Kabupaten_Gresik. 